\title{
Phytophthora cinnamomi as a Contributor to White Oak Decline in Mid-Atlantic United States Forests
}

\author{
M. E. McConnell and Y. Balci, Department of Plant Science and Landscape Architecture, University of Maryland, College Park, MD
} 20742

\begin{abstract}
McConnell, M. E., and Balci, Y. 2014. Phytophthora cinnamomi as a contributor to white oak decline in mid-Atlantic United States forests. Plant Dis. $98: 319-327$.

To evaluate Phytophthora cinnamomi as a cause of white oak (Quercus alba) decline in mid-Atlantic forests, sampling was conducted at 102 sites from 2011 to 2012. Soil and roots from healthy and declining white oak trees were collected. Phytophthora spp. were isolated using baiting and CFU of $P$. cinnamomi quantified using wet-sieving. Fine roots were scanned and measured. Phytophthora spp. were isolated from $43 \%$ of the sites. P. cinnamomi was common; six other species were isolated infrequently. Little difference in lesion size existed on white oak seedlings inoculated with 32 isolates of $P$. cinnamomi; only

nine other hosts did not have significantly different CFU. P. cinnamomi was restricted to United States Department of Agriculture hardiness zones six and seven and never found in zone five. The presence of Phytophthora spp. in soil can be associated with white oak fine root health. When Phytophthora spp. were present, white oak trees in zones five and six had less fine roots. In mid-Atlantic oak forests, however, environmental conditions appear to play a key role in determining the impact of $P$. cinnamomi on the root system. P. cinnamomi alone does not appear to be a causal factor of white oak decline.
\end{abstract} 13 isolates caused significant mortality. Soils from white oak versus
Decline of tree species in both the red and white oak groups is an ongoing occurrence in U.S. forests, and reports of oak decline have become more frequent $(1,23,26)$. Oak decline is considered to be a disease complex, meaning eventual mortality occurs due to the interaction of abiotic and biotic factors over time, which often makes determining the cause of mortality difficult $(26,39)$. Historically, oak species became dominant in eastern U.S. forests due to clear-cutting and burning, because oak species have the ability to quickly regenerate after disturbances $(1,48,65)$. Once American chestnut populations were decimated by blight, oak also colonized former chestnut sites (48). Eventually, agricultural methods evolved and the widespread practices of clear-cutting and controlled burning were discontinued, resulting in forests becoming shadier and wetter as canopies filled in. The new climate conditions in many forests resulted in increased competition from species such as maple, cherry, and hemlock, which are better adapted to moist, low-light areas (48). In addition to changing forest composition, documented contributors to oak decline in the United States include inciting factors such as multiyear droughts, gypsy moth (Lymantria dispar) defoliation, and contributing factors such as boring insect damage and Armillaria root rot $(17,21,37)$.

A greater incidence of decline was described on red oak compared with white oak, especially in the Appalachian Mountains and Ozark Highlands of Arkansas, Oklahoma, and Missouri $(21,49,60)$. Causes of decline were most often described as prolonged drought, Armillaria spp. infection, and insect damage. However, several studies have noted that white oak (Quercus alba), in particular, has experienced significant decline in the eastern United States in recent years $(1,10,23,46)$. Many of these trees are growing at sites with seemingly adequate resources; therefore, the loss of vigor is puzzling. Adverse long-term climate and site factors combined

Corresponding authors:

M. E. McConnell, E-mail: megmcconnell3@gmail.com

and Y. Balci, E-mail: ybalci@umd.edu

Accepted for publication 24 September 2013.

http://dx.doi.org/10.1094/PDIS-06-13-0649-RE

(C) 2014 The American Phytopathological Society with insect defoliation and boring are cited as the probable causes of white oak decline, while thorough investigation of soilborne pathogens is often lacking $(21,36,38,59)$. The fungal pathogens usually associated with root mortality of white oak in U.S. forests are Armillaria spp.; little else is reported (15,37). In European oak declines, Phytophthora spp., especially Phytophthora cinnamomi, are proven contributors to the disease complex $(8,9,13,14$, $16,34,52)$. The pathogen causes fine and lateral root mortality, as well as crown and trunk cankers of several oak species in Europe. P. cinnamomi also causes cankers on oak in Mexico, Florida, and California $(2,25,61,70)$. Surveys by Balci and colleagues indicate that, although other species of Phytophthora are present, $P$. cinnamomi is the most widely distributed species in eastern U.S. oak forests $(5,7)$. A recent study conducted in southern Ohio determined that declining white oak at sites infested with $P$. cinnamomi had significantly lower amounts of fine roots than white oak trees at noninfested sites, illustrating a tentative association between $P$. cinnamomi and white oak decline (10). Another study conducted in the same vicinity determined that population levels of $P$. cinnamomi were significantly higher in soil collected from declining white oak trees, providing further impetus to examine this possible association (46). This study was conducted to more thoroughly investigate the association of $P$. cinnamomi with white oak decline in the mid-Atlantic region. The role of $P$. cinnamomi in affecting root health and its distribution, host preferences, and differences in pathogenicity were also investigated in an effort to gather information for future management strategies.

\section{Materials and Methods}

Study site selection. Forest stands containing healthy and declining white oak were identified in collaboration with United States Department of Agriculture (USDA) Forest Service forest health and state department of agriculture personnel. Several sites were also selected from stands identified during previous surveys (5). In total, 102 sites in Delaware, Maryland, West Virginia, Ohio, Pennsylvania, New York, and Connecticut were sampled in 2011 (37 sites) and 2012 (65 sites) (Fig. 1). The majority of the sites were located in state-owned parks and forests (73 sites), with a further 24 sites located on private property and the final 5 sites on state university-owned land. Sites located in USDA hardiness zones five, six, and seven were selected in order to determine the 
possible northern range of $P$. cinnamomi (Fig. 1) (3). The average yearly range of soil temperatures for the past 10 years are 1.4 to $16.0,1.2$ to 25.3 , and 4.9 to $27.6^{\circ} \mathrm{C}$ for zones five, six, and seven respectively (64). Eight sites that resulted in soil baits negative for Phytophthora in 2011 were sampled again in 2012 to determine if they were truly negative or if the inoculum level was too low for detection upon initial collection $(5,20,67)$.

Sampling procedure by site. Sampling was generally restricted to spring and early summer each year to ensure that fine roots were harvested at roughly the same point in the white oak life cycle, as well because of as the fact that increased isolation success of Phytophthora spp. occurs during spring (5). Sampling occurred from May to July 2011 and April to June 2012. The northernmost sites in New York and Connecticut were visited in September 2012, because high summer temperatures prevented continued sampling.

Oak trees sampled (408 in total) were an average of 91 years old and had an average dbh of $41 \mathrm{~cm}$. Each site comprised two healthy and two declining white oak trees selected randomly within a 50-m radius. If only healthy or only declining white oak trees were present, four trees in the same condition were sampled. The surface layer of organic matter was scraped away with a pickaxe and four pits, roughly 30 by 30 by $30 \mathrm{~cm}$ in size, were dug in the cardinal directions approximately 1 to $1.5 \mathrm{~m}$ away from the trunk. Approximately $400 \mathrm{~g}$ of soil was collected from each soil pit and combined in a plastic resealable bag. All oak roots $<1 \mathrm{~cm}$ in diameter were collected from the four soil pits for future scanning (10). Samples were refrigerated at $5^{\circ} \mathrm{C}$ or stored in coolers with ice until they were transported to the lab, then kept at $5^{\circ} \mathrm{C}$ until processing. Samples were processed within 2 months of collection date. Tree health was assessed based on the percentage of visible crown dieback. Crowns were rated based on the following criteria: class one, no decline symptoms, crown transparency less than 10 to
$15 \%$; class two, slight damage, some branch dieback and small gaps in lateral branch system, transparency 15 to $35 \%$; class three, moderate twig and branch dieback, large gaps in lateral branch system, chlorosis and wilting of leaves, growth of epicormic shoots, transparency 35 to $55 \%$; class four, severe branch dieback, many gaps in crown, chlorosis and loss of most leaves, many epicormic shoots, transparency 55 to $75 \%$; and class five, dying tree, over $75 \%$ defoliated $(5,9)$.

In 2012, soil was also collected from the most prevalent nonwhite oak possible alternate hosts of Phytophthora spp. within the same 50-m radius at each site, in a manner identical to the white oak soil sampling procedure. This was done in order to determine whether other plants were acting as alternate hosts or inoculum reservoirs of $P$. cinnamomi. Alternative hosts sampled included various shrub and tree species (Table 1).

Soil texture of each sample was determined in an attempt to evaluate any connection with the presence or absence of Phytophthora spp. in the soil at each site. In order to classify each soil, the California Soil Resource Lab's online SoilWeb mapping tool was used. Global positioning system coordinates were entered for each site and soil type was located on the SoilWeb maps (50).

Isolation of Phytophthora spp. from soil. Bags containing soil from the four soil pits were mixed thoroughly and $300 \mathrm{~g}$ of each soil sample was placed in a plastic container $(19.5$ by 14 by $9 \mathrm{~cm})$ with lid, flooded with $500 \mathrm{ml}$ of distilled water, and baited by floating $Q$. robur (English oak) leaflets on the water surface for 3 to 5 days at 17 to $18^{\circ} \mathrm{C}$ in the dark. Organic debris floating on the water surface was removed prior to placing the bait leaflets. In 2011, soil samples were first baited with rhododendron leaves (Rhododendron maximum) but, due to low isolation results, an additional $300 \mathrm{~g}$ of each negative soil sample was baited a second time with English oak leaflets. In 2012, all soil samples were

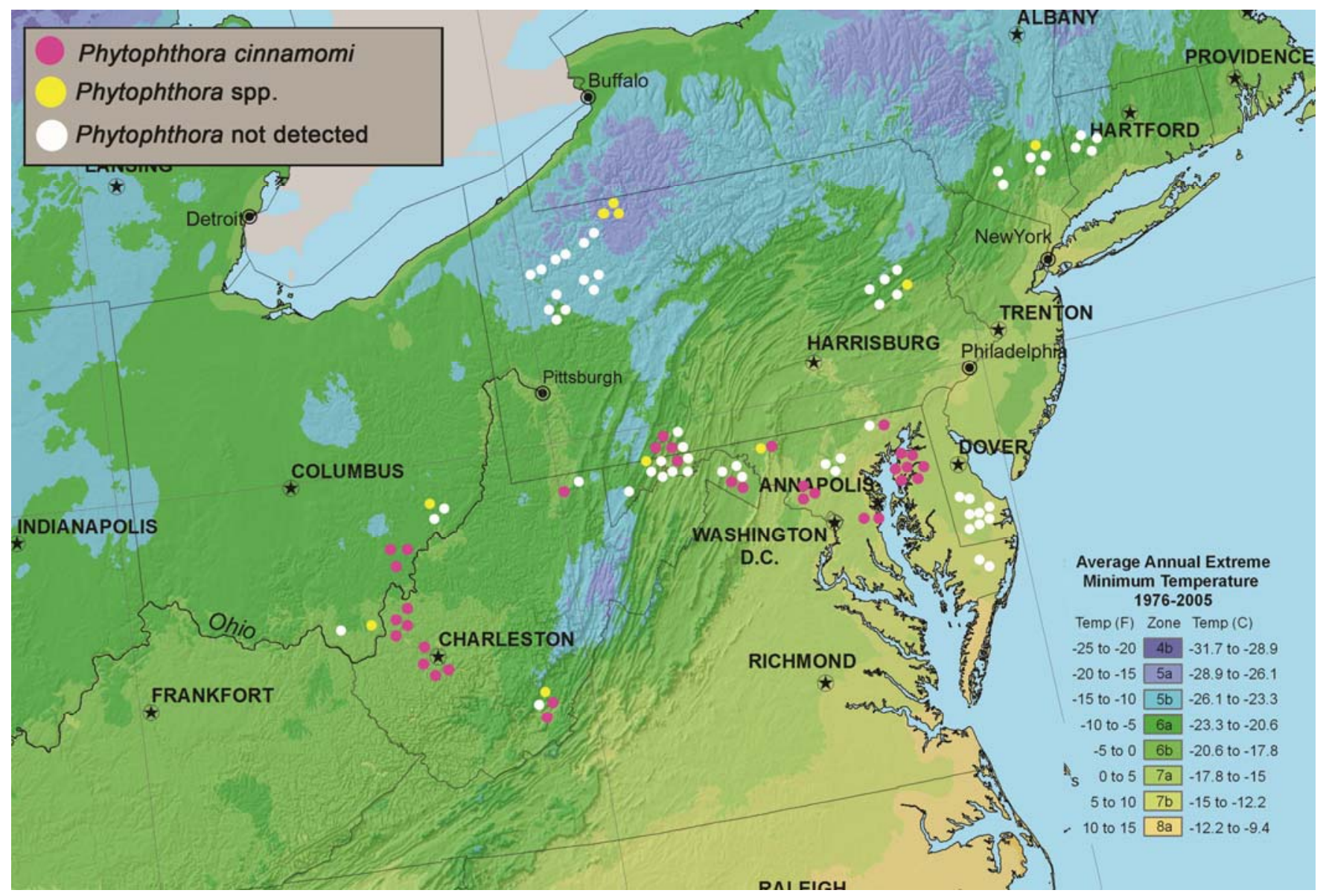

Fig. 1. Geographical distribution of Phytophthora cinnamomi and six other Phytophthora spp. Study site locations were mapped within United States Department of Agriculture plant hardiness zones. 
baited using English oak leaflets. Discolored areas or lesions that developed on the bait leaflets were examined microscopically for the presence of sporangia characteristic of Phytophthora spp. and, if present, plated on clarified V8-based PARPNH (with pimaricin at $10 \mu \mathrm{g} / \mathrm{liter}$, ampicillin at $200 \mu \mathrm{g} / \mathrm{liter}$, rifampicin at $10 \mu \mathrm{g} / \mathrm{ml}$, pentachloronitrobenzene at $25 \mu \mathrm{g} / \mathrm{liter}$, nystatin at $50 \mu \mathrm{g} / \mathrm{liter}$, and hymexazol at $50 \mu \mathrm{g} / \mathrm{liter})$ media for isolation $(5,9,10,32)$. Clarified V8 (cV8) was prepared by first adding $10 \mathrm{~g}$ of $\mathrm{CaCO}_{3}$ to 1 liter of $\mathrm{V} 8$ juice, then spinning down the buffered vegetable juice in $50-\mathrm{ml}$ centrifuge tubes at $4,000 \mathrm{rpm}$ for $10 \mathrm{~min}$ to remove the solid vegetable matter.

Isolate characterization. Isolates of Phytophthora were identified based on both morphological features and molecular sequence data. Isolates were grown for 2 to 4 weeks on $\mathrm{cV} 8$ agar in order to observe hyphal morphology and chlamydospore and oospore characteristics. Subsets of heterothallic isolates were paired with A1 and A2 tester isolates of $P$. cinnamomi by placing mycelial plugs of known and unknown mating types on $\mathrm{cV} 8$ agar opposite one another (20). After 2 weeks, oospore formation was examined along the border where mycelia met. Sporangia for each isolate were produced by removing three to five agar plugs with mycelia from the leading edge of each colony growing on cV8 and flooding the plugs with nonsterile soil-extract solution (NS-SES). The agar plugs were checked for sporangia after incubating at room temperature overnight; if none were present, the plug containers were drained, new NS-SES was added, and the procedure repeated daily until sporangia were produced. Characteristics and sizes of 20 sporangia, chlamydospores, and oospores were measured and compared using a dichotomous key and species descriptions $(20,41)$.

For molecular identification, isolates were grown in potato dextrose broth (Difco) for 5 to 10 days at $17^{\circ} \mathrm{C}$ on a laboratory bench top. Excess broth was removed using a pipet and mycelium was lyophilized for $12 \mathrm{~h}$. For each isolate, approximately $0.1 \mathrm{mg}$ of lyophilized mycelia was transferred to $0.2-\mathrm{ml}$ polymerase chain reaction (PCR) strip tubes using a sterile tooth pick, and genomic DNA was extracted by adding $10 \mu \mathrm{l}$ of Lyse and Go PCR Reagent (Thermo Scientific Pierce) to each tube and following the manufacturer's instructions for extraction. The internal transcribed spacer (ITS) region was amplified and sequenced (MCLAB) using primers ITS6 or ITS4 (68). Low-quality sequences were eliminated and the procedure was repeated with new material. Sequences were aligned and edited using Geneious Pro 5.5.6 Software (Biomatter Ltd.) and compared with known DNA sequences in the National Center for Biotechnology Information database using BLAST searches. GenBank accession numbers were obtained for representative isolates only.

Quantification of $P$. cinnamomi CFU. To quantify CFU of $P$. cinnamomi in soil, a modified wet-sieving method was used. Three $50-\mathrm{g}$ subsamples of each soil sample positive for $P$. cinnamomi were homogenized in $300 \mathrm{ml}$ of distilled water at low speed in a Waring laboratory blender for 5 to $30 \mathrm{~s}$, depending on soil texture, because fine-textured soils required more time. The blended slurry was filtered and rinsed through nested 850-, 250-, 125- and 38- $\mu \mathrm{m}$ sieves in order to collect chlamydospores of $P$. cinnamomi (57). The material remaining on the $38-\mu \mathrm{m}$ sieve was rinsed a final time and collected in 30 to $70 \mathrm{ml}$ of distilled water in a $100-\mathrm{ml}$ beaker, then plated on cV8-PARPNH selective medium (approximately 15 to $20 \mathrm{ml} /$ plate). After incubation in complete darkness at $18^{\circ} \mathrm{C}$ for 3 days, petri dishes were rinsed free of soil and colonies of $P$. cinnamomi were counted $(10,57)$. CFU were calculated based on colony count per $100 \mathrm{~g}$ of soil; data were corrected by calculating the dry weight of two $50-\mathrm{g}$ subsamples for each soil sample analyzed.

Fine root processing. Collected roots were placed in a basin in the sink and rinsed with a hose to remove all soil. Any white oak roots were identified based on characteristic morphology and all others were discarded. Remaining white oak roots were scanned with the WinRHIZO Pro 5.0 program (Regent Instruments) to determine fine root (diameter of 0 to $1.5 \mathrm{~mm}$ ) lengths and amounts (10).
Stem inoculations. $P$. cinnamomi isolates collected in 2011 were tested using a seedling stem inoculation assay to establish any differences in aggressiveness between the isolates. One-year-old white oak seedlings obtained from Maryland's John S. Ayton State Forest Tree Nursery were established in groups of 10 seedlings per 19-liter pot in the greenhouse prior to the start of the experiment. Efforts were made to select seedlings of similar size when transplanting. Overly large and small seedlings were excluded. Before the test began, seedlings were maintained using drip irrigation for 3 months. In all, 32 isolates of $P$. cinnamomi recovered from the rhizosphere soil of white oak trees in 2011 were used. A container of 10 seedlings was used for inoculation with each isolate (one replicate per isolate). Inoculum consisted of 6-mm plugs cut from the growing edge of 7-day-old colonies of $P$. cinnamomi grown on cV8 agar at $20^{\circ} \mathrm{C}$. Control inoculum consisted of 6-mm plugs cut from sterile cV8 agar plates. Seedlings were wounded with a sterile razor blade about $3 \mathrm{~cm}$ above the soil line, inoculated with agar plugs, covered with a layer of sterile moist cotton, and sealed using Parafilm. After 2 months, the Parafilm and cotton were removed and bark tissue slightly shaved away to reveal any developing lesions (6). Seedlings that remained alive were measured and analyzed for lesion formation, but seedlings that died during the two-month incubation period were not included in lesion size analysis. Seedling mortality was monitored and analyzed separately.

Statistical analyses. Possible connections between the crown status of white oak, soil texture, and occurrence of Phytophthora spp. were analyzed using contingency tables and by conducting two-tailed Fisher's exact tests. Logistic regression analysis was conducted to evaluate any connection between the root status and crown dieback when Phytophthora spp. were present and absent. Stem lesion sizes on inoculated seedlings were analyzed using analysis of variance, and Tukey's multiple comparison test was performed to separate any differences between the isolates tested. The seedling mortality rates were analyzed using the KruskalWallis nonparametric test. Significant differences were set at $P \leq$ 0.05 and the software JMP 10.0.2. was used for all statistical evaluations (SAS Institute Inc., Cary, NC).

Table 1. Phytophthora spp. isolated from rhizosphere soil samples collected in mid-Atlantic oak forests from 2011 to 2012

\begin{tabular}{|c|c|c|c|}
\hline Host & $n$ & $\begin{array}{l}\text { Positive } \\
\text { samples }\end{array}$ & Phytophthora spp. ${ }^{\mathrm{a}}$ \\
\hline Acer pennsylvanicum & 1 & 0 & \\
\hline A. rubrum & 48 & 10 & $\begin{array}{l}\text { Phytophthora cambivora }(1) \\
\text { P. cinnamomi }(8) \\
\text { P. quercetorum }(1)\end{array}$ \\
\hline A. saccharum & 23 & 10 & $\begin{array}{l}\text { P. cambivora }(3) \\
\text { P. cinnamomi }(5) \\
P \text {. plurivora }(2)\end{array}$ \\
\hline Carya sp. & 2 & 0 & $\ldots$ \\
\hline Castanea dentata & 2 & 0 & $\ldots$ \\
\hline Fagus grandifolia & 11 & 4 & P. cinnamomi (4) \\
\hline Hamemelis virginiana & 12 & 0 & $\ldots$ \\
\hline Ilex ораса & 3 & 0 & $\ldots$ \\
\hline Kalmia latifolia & 4 & 1 & P. cinnamomi (1) \\
\hline Liriodendron tulipifera & 1 & 1 & P. cinnamomi (1) \\
\hline Quercus alba & 408 & 91 & $\begin{array}{l}\text { P. cambivora }(10) \\
P . \text { cinnamomi }(72) \\
P . \text { cryptogea }(1) \\
P . \text { europaea }(4) \\
P . \text { pini }(1) \\
P . \text { plurivora }(1) \\
P . \text { quercetorum }(2)\end{array}$ \\
\hline Q. coccinea & 1 & 0 & $\ldots$ \\
\hline Q. falcata & 2 & 0 & $\ldots$ \\
\hline Q. prinus & 11 & 4 & P. cinnamomi (4) \\
\hline Q. rubra & 37 & 5 & P. cinnamomi (5) \\
\hline$Q$. velutina & 6 & 1 & P. cinnamomi (1) \\
\hline Vaccinium sp. & 18 & 1 & P. cinnamomi (1) \\
\hline
\end{tabular}

a Numbers in parentheses represent isolates recovered from individual trees. 


\section{Results}

Overall, an approximately equal number of healthy $(n=200)$ and declining $(n=208)$ white oak trees were sampled. Usually, declining trees were scattered within each stand; there were no sites with widespread areas of continuous decline.

Phytophthora spp.-associated bleeding trunk cankers were not detected at any of the sampling sites. When trees at each sampling site were inspected for other potential pathogens, no signs of Armillaria or Biscogniauxia spp. were observed. Although rhizomorphs of Armillaria were present at some sites, no fruiting structures or mycelial fans were evident on any sampled trees.

Isolation results and species assemblage. Phytophthora spp. were isolated from 43\% of all sites sampled between 2011 and 2012 (44 positive out of 102 sites; Fig. 1). When eight sites that were Phytophthora-negative in 2011 were revisited in 2012, only one of these sites resulted in the isolation of a Phytophthora sp. Phytophthora spp. ultimately were isolated from soil from 10 of 17 plant species (Table 1). Trees in the genera Acer, Fagus, and Quercus commonly yielded Phytophthora spp. but Phytophthora spp. were almost never found beneath the understory shrub species Hamamelis virginiana, Kalmia latifolia, and Vaccinium sp.

In total, 622 soil samples were collected. This included soil from 408 white oak trees ( 32 of them resampled a second time) and 182 other hosts. In all, 101 samples yielded colonies of Phytophthora upon the first baiting, and a further 31 samples yielded positive results after they were air dried, reflooded, and baited a second time (Table 1). In 2011, two plant species were used for baiting. When rhododendron leaves resulted in no isolation of Phytophthora spp., the samples were rebaited using English oak leaf-

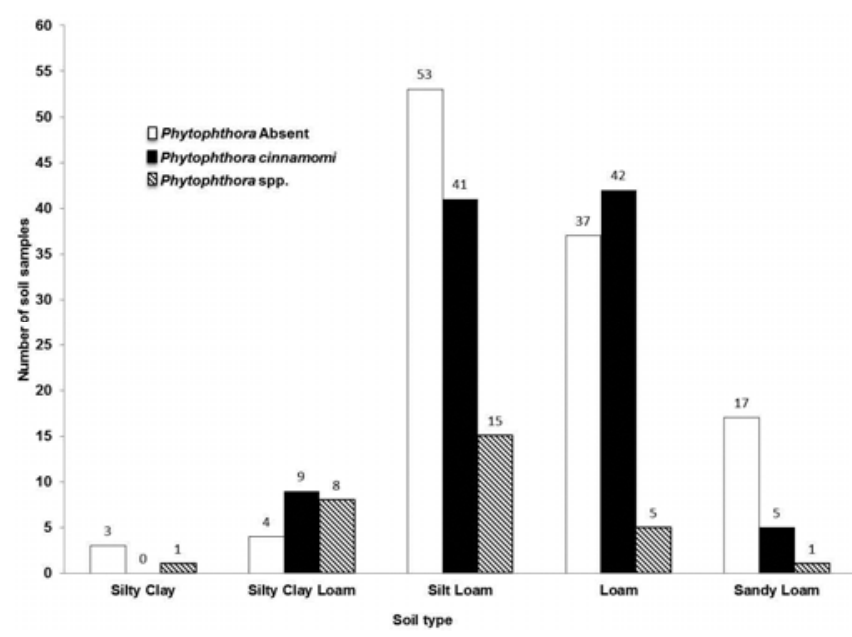

Fig. 2. Frequency of isolation of Phytophthora from different soil types at infested sites. Phytophthora spp. excludes Phytophthora cinnamomi and represents all other species isolated, including P. cambivora, $P$. cryptogea, $P$. europaea, $P$. pini, $P$. plurivora, and $P$. quercetorum. lets. This resulted in the isolation of Phytophthora spp. from an additional 12 soil samples.

Seven different species of Phytophthora were isolated during the study, all of which have been previously described (Table 1). $P$. cinnamomi (GenBank accession number KF271786) was the most frequently isolated species, accounting for $70 \%$ of Phytophthorapositive sites (31 sites in total). At five sites, P. cinnamomi was isolated together with one or more species of Phytophthora, though from soil from different hosts. When $P$. cinnamomi-infested sites were analyzed for frequency of isolation of the pathogen from plant species present, $47 \%$ of all plants at an infested site were predicted to harbor the pathogen (likelihood ratio $\chi^{2}=92.1 ; P<$ 0.0001). The second most commonly encountered species was $P$. cambivora (GenBank accession number KF271790), which was isolated from seven sites. Other Phytophthora spp. were isolated sporadically and included $P$. cryptogea (GenBank accession number KF271791), $P$. europaea (GenBank accession number KF271788), $P$. pini (GenBank accession number KF271787), $P$. plurivora (GenBank accession number KF271789), and $P$. quercetorum (GenBank accession number KF271785) (Table 1). Only the A2 mating type was present when a subset of isolates of $P$. cinnamomi and all isolates of $P$. cambivora were tested. One isolate of $P$. cambivora was homothallic and oogonia characteristic of the species formed readily without an opposite mating type.

Incidence of Phytophthora in relation to USDA hardiness zones, soil type, and white oak crown status. $P$. cinnamomi was isolated only from sites in USDA hardiness zones six and seven, and not found further north in zone five (Fig. 1). Other Phytophthora spp. were isolated from all hardiness zones, including sites in zone five.

One or more species of Phytophthora were isolated from all soil types but the loamy sand collected from Delaware. P. cinnamomi was isolated more frequently from silt loam and loam-type soils, whereas the other Phytophthora spp. were distributed more evenly throughout the five Phytophthora-positive soil types (Fig. 2). P. cinnamomi was isolated approximately three times more often than other species of Phytophthora from silt loam soils, and nearly nine times more often than other species from loam-textured soils. When occurrences of Phytophthora spp. at infested sites were compared for soil textures across the study sites, only $P$. cinnamomi was more often associated with loam soils $(P=0.028)$. The occurrence of other Phytophthora spp. was not associated with silt loams $(P=0.844)$, silty clays $(P=0.982)$, or sandy loams $(P=$ 0.112).

No associations were found between the crown symptoms and presence of Phytophthora spp. at infested sites during 2011 or 2012 (Table 2). During both years, P. cinnamomi was isolated approximately twice as often from soil from healthy white oak than from declining white oak. In contrast, other species of Phytophthora were isolated more often from declining trees than healthy trees, though this trend was not significant (Table 2).

CFU of $P$. cinnamomi in relation to crown dieback, host type, and hardiness zone. Numbers of $P$. cinnamomi $\mathrm{CFU}$ in soil were

Table 2. Isolation frequency of Phytophthora spp. and Phytophthora cinnamomi associated with soil samples collected from white oak trees at infested sites

\begin{tabular}{|c|c|c|c|c|c|}
\hline \multirow[b]{2}{*}{ Year } & \multirow[b]{2}{*}{ Phytophthora status $^{\mathrm{b}}$} & \multicolumn{2}{|c|}{ Crown status $^{\mathrm{a}}$} & \multirow[b]{2}{*}{$\chi^{2}$} & \multirow[b]{2}{*}{$P>\chi^{2}$} \\
\hline & & Healthy & Declining & & \\
\hline \multirow{3}{*}{2011} & Absent & 16 & 18 & & \\
\hline & P. cinnamomi & 15 & 11 & 0.667 & 0.4141 \\
\hline & Phytophthora spp. & 2 & 6 & 1.287 & 0.2566 \\
\hline \multirow[t]{3}{*}{2012} & Absent & 53 & 27 & . & 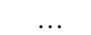 \\
\hline & P. cinnamomi & 48 & 23 & 0.031 & 0.8598 \\
\hline & Phytophthora spp. & 12 & 10 & 1.023 & 0.3119 \\
\hline \multirow[t]{3}{*}{$2011-12$} & Absent & 69 & 45 & $\ldots$ & \\
\hline & P. cinnamomi & 63 & 34 & 0.438 & 0.5083 \\
\hline & Phytophthora spp. & 14 & 16 & 1.868 & 0.1717 \\
\hline
\end{tabular}

${ }^{a}$ Declining trees were characterized as trees displaying $>15 \%$ crown transparency, chlorosis of leaves, tip and shoot dieback, gaps in lateral branch system, and growth of epicormic shoots.

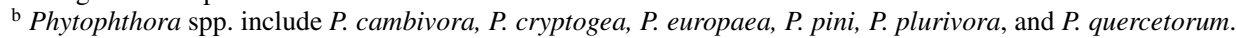


quite variable over the study area, ranging from undetectable levels to a maximum of $118.5 \mathrm{CFU}$ per $100 \mathrm{~g}$ of soil. In one instance, we isolated P. cinnamomi from soil collected from Vaccinium spp. with baiting; however, no viable CFU were detected with the wetsieving method. The CFU from 2011 samples (average of $20 \pm 31$ ) were not significantly different from 2012 (average of $19 \pm 36)(P$ $=0.8037)$. This was also not significantly different when the average CFU were compared between healthy and declining trees in both sampling years (2011: healthy $=19 \pm 32$, declining $=22 \pm 31$, $P=0.8343 ; 2012$ : healthy $=21 \pm 27$, declining $=15 \pm 25, P=$ 0.3955). Similarly, no significant differences were detected in CFU of soils collected from diverse hosts sampled, though soil collected from the genera Acer, Fagus, and Quercus had the highest CFU levels (Table 3). When CFU were analyzed in relation to USDA hardiness zones, soils from the more southern zone seven had

Table 3. CFU and standard deviations (Stdev) of Phytophthora cinnamomi per $100 \mathrm{~g}$ of soil for various hosts sampled

\begin{tabular}{lrc}
\hline Host & $\boldsymbol{n}$ & Mean \pm Stdev \\
\hline Acer rubrum & 10 & $18 \pm 37$ \\
A. saccharum & 3 & $15 \pm 5$ \\
Fagus grandifolia & 3 & $34 \pm 44$ \\
Kalmia latifolia & 1 & 3 \\
Liriodendron tulipifera & 1 & 1 \\
Quercus alba & 73 & $18 \pm 26$ \\
Q. prinus & 4 & $41 \pm 39$ \\
Q. rubra & 3 & $28 \pm 15$ \\
Q. velutina & 1 & 34 \\
\hline
\end{tabular}

Table 4. Mean colony counts (CFU) and standard deviations (Stdev) per $100 \mathrm{~g}$ of soil of Phytophthora cinnamomi in United States Department of Agriculture hardiness zones six and seven

\begin{tabular}{lcccc}
\hline Year, zone & $\boldsymbol{n}$ & Mean \pm Stdev & $\boldsymbol{F}$ value & $\boldsymbol{P}>\boldsymbol{F}$ \\
\hline 2011 & & & & \\
6 & 12 & $16.6 \pm 29.6$ & 0.29998 & 0.5891 \\
7 & 14 & $23.3 \pm 32.4$ & $\ldots$ & $\ldots$ \\
2012 & & & & \\
6 & 42 & $13.4 \pm 23.3$ & 4.1411 & 0.0455 \\
7 & 32 & $25.6 \pm 28.1$ & $\ldots$ & $\ldots$ \\
$2011-12$ & & & & \\
6 & 54 & $14.3 \pm 24.6$ & 4.0232 & 0.0476 \\
7 & 46 & $24.9 \pm 29.2$ & $\ldots$ & $\ldots$ \\
\hline
\end{tabular}

greater CFU than soil collected from the relatively cooler zone six; this was significant in the second year and also when the data for both years were combined (Table 4).

White oak fine root status in relation to sampling year, hardiness zone, crown status, and presence of Phytophthora spp. Total white oak fine roots ( 0 to $1.5 \mathrm{~mm}$ in diameter) collected in 2011 and 2012 differed significantly between sampling years. Therefore, fine root data were separately analyzed for each year. Far fewer fine roots were present in the second year of the study (average in $2011=3,457 \mathrm{~cm}$ and in $2012=2110 \mathrm{~cm} ; P<0.0001$ ). Amounts of fine roots collected also differed between hardiness zones. In 2011, significantly fewer fine roots were detected in zone five compared with zones six and seven $(P<0.0001)$. This was also true in $2012(P<0.0001)$.

Mean fine root lengths varied between hardiness zones when the presence and absence of Phytophthora spp. was a factor (Table 5). Where $P$. cinnamomi was absent in zone five, trees affected by other Phytophthora spp. resulted in a significant decrease in fine root amounts during 2011 and 2012. In zone six, where $P$. cinnamomi was the most frequently isolated species, a decrease in fine roots in the presence of Phytophthora spp. was observed but was significant only in 2012. Although $P$. cinnamomi was also the most frequently isolated species in zone seven, white oak trees had significantly greater amounts of fine roots when Phytophthora spp. were present in both years of the study (Table 5). This was in contrast to zones five and six, where fewer roots were found when Phytophthora spp. were present.

In 2011, trees at sites where no Phytophthora spp. were detected had similar amounts of fine roots regardless of the crown status $(P$ $=0.8202$ ). In contrast, when P. cinnamomi or other Phytophthora spp. were present, a significant negative correlation was found between the crown status of trees and the amount of fine roots present $(P=0.0022$ and $P=0.0201$, respectively). In 2012 a different result was obtained. Regardless of the presence of Phytophthora, declining trees had fewer fine roots $(P=0.0036)$. Interestingly, more fine roots were present on declining trees when other Phytophthora spp. were present $(P=0.0360)$, although this was not significant for areas infested with $P$. cinnamomi $(P=$ 0.4712)

Stem inoculation experiment. In all, 29 of 32 isolates caused lesions that were significantly different from the control inoculations (Fig. 3). Isolates that caused significant lesions differed slightly in their aggressiveness. However, stem lesion lengths did

Table 5. Mean total fine root lengths $(\mathrm{cm})$ and standard deviations collected from four soil pits $(30 \times 30 \times 30 \mathrm{~cm})$ of white oak trees at sites infested with or free of Phytophthora in both sampling years and at different United States Department of Agriculture hardiness zones

\begin{tabular}{|c|c|c|c|c|c|c|c|}
\hline \multirow[b]{2}{*}{ Year, zone } & \multirow[b]{2}{*}{ Root diameter (mm) } & \multicolumn{4}{|c|}{ Mean total fine root lengths $(\mathrm{cm})^{\mathrm{a}}$} & \multirow[b]{2}{*}{$F$ value } & \multirow[b]{2}{*}{$P>F^{\mathrm{b}}$} \\
\hline & & $n$ & Absent & $n$ & Present & & \\
\hline \multicolumn{8}{|l|}{2011} \\
\hline \multirow[t]{3}{*}{5} & $0-0.5$ & 24 & $1,123 \pm 543$ & 4 & $618 \pm 422$ & 3.106 & 0.0898 \\
\hline & $0.5-1$ & 24 & $456 \pm 183$ & 4 & $271 \pm 191$ & 3.4426 & 0.0749 \\
\hline & $1-1.5$ & 24 & $249 \pm 91$ & 4 & $144 \pm 88$ & 4.5713 & 0.0421 \\
\hline \multirow[t]{3}{*}{6} & $0-0.5$ & 28 & $3,010 \pm 2,244$ & 32 & $2,658 \pm 1,482$ & 0.5265 & 0.471 \\
\hline & $0.5-1$ & 28 & $1,069 \pm 738$ & 32 & $1,040 \pm 541$ & 0.0311 & 0.8606 \\
\hline & $1-1.5$ & 28 & $541 \pm 341$ & 32 & $532 \pm 269$ & 0.0135 & 0.9079 \\
\hline \multirow[t]{3}{*}{7} & $0-0.5$ & 24 & $1,523 \pm 1,176$ & 24 & $2,747 \pm 2,078$ & 6.3156 & 0.0155 \\
\hline & $0.5-1$ & 24 & $517 \pm 391$ & 24 & $1,019 \pm 755$ & 8.3817 & 0.0058 \\
\hline & $1-1.5$ & 24 & $258 \pm 191$ & 24 & $498 \pm 367$ & 8.0792 & 0.0067 \\
\hline \multicolumn{8}{|l|}{2012} \\
\hline \multirow[t]{3}{*}{5} & $0-0.5$ & 40 & $763 \pm 77$ & 8 & $393 \pm 171$ & 3.8826 & 0.0548 \\
\hline & $0.5-1$ & 40 & $354 \pm 34$ & 8 & $177 \pm 77$ & 4.3943 & 0.0416 \\
\hline & $1-1.5$ & 40 & $207 \pm 20$ & 8 & $100 \pm 44$ & 4.8909 & 0.032 \\
\hline \multirow[t]{3}{*}{6} & $0-0.5$ & 40 & $1,739 \pm 136$ & 56 & $1,499 \pm 115$ & 1.8278 & 0.1796 \\
\hline & $0.5-1$ & 40 & $832 \pm 59$ & 56 & $663 \pm 50$ & 4.7402 & 0.032 \\
\hline & $1-1.5$ & 40 & $474 \pm 32$ & 56 & $363 \pm 27$ & 7.0935 & 0.0091 \\
\hline \multirow[t]{3}{*}{7} & $0-0.5$ & 32 & $884 \pm 782$ & 28 & $1,186 \pm 750$ & 2.3117 & 0.1338 \\
\hline & $0.5-1$ & 32 & $423 \pm 367$ & 28 & $617 \pm 375$ & 4.0941 & 0.0476 \\
\hline & $1-1.5$ & 32 & $237 \pm 199$ & 28 & $323 \pm 186$ & 2.9414 & 0.0917 \\
\hline
\end{tabular}

${ }^{\text {a }}$ Phytophthora spp. absent or present.

${ }^{\mathrm{b}}$ Significant differences are marked in bold $(P>0.05)$. 
not always correlate with seedling mortality rates. Only 13 of the 32 isolates tested caused significant mortality to white oak seedlings. This discrepancy was best illustrated for the isolates MDDK1-1 and WV-WVU1-3, which did not cause lesions that were significantly different from the controls but did cause significant seedling mortality (Fig. 3).

\section{Discussion}

Similar to previous studies in eastern U.S. and European oak forests, about half of the sites surveyed in our study were infested with Phytophthora spp. $(5,9,32,34,66)$. The species assemblage of Phytophthora identified in our study was similar to previous oak forest surveys in the eastern United States, except for P. cryptogea, which has not been previously isolated $(5,10,44)$. The species assemblage also largely overlaps with European oak forest surveys; the major difference is that $P$. quercina is the most commonly encountered species in Europe and $P$. cinnamomi is the most common species in eastern oak forests $(8,9,29,31,32,34,66)$. In addition, $P$. quercetorum is only known to exist in U.S. oak forests (4).

Rebaiting soils after they were air dried improved isolation success. This procedure proved to be a useful method to stimulate germination of dormant structures of Phytophthora spp. Allowing soils to dry before baiting again may have also lowered populations of other competitive soil microorganisms, allowing any Phytophthora spp. present to be isolated more easily. Five species, including $P$. cambivora, $P$. cinnamomi, $P$. cryptogea, $P$. europaea, and $P$. quercetorum, were detected after this procedure. Such results were obtained in other studies and, thus, the procedure was suggested to increase isolation frequency of homothallic species that produce extensive oospores in culture media such as $P$. quercina, $P$. quercetorum, and $P$. cactorum $(5,9,28,34)$. In our study, air-drying soil before rebaiting increased the isolation frequency of both hetero- and homothallic species. The heterothallic species $P$. cinnamomi was isolated in 18 instances only after soil was subject to air-drying after the first isolation attempt failed. In Western Australia, where P. cinnamomi is widespread in the eucalyptus forests, survival structures other than chlamydospores (oospores and hyphal aggregates) have been detected (35). Mimicking the periodically dry conditions of temperate areas when baiting may stimulate the growth of these various survival structures and prove to be a useful method to detect Phytophthora spp. in eastern U.S. oak forests.

Many different plant species have been used to bait Phytophthora spp. from soil and, although this was not an objective of the study, we did observe that English oak leaflets were more sensitive as bait material; they resulted in twice the number of Phytophthora isolations compared with rhododendron leaves when both baits were used during the first year of the study. One reason for the increased isolation frequency could be the opportunity to examine English oak leaflets for sporangia of Phytophthora spp. with a compound microscope, whereas rhododendron leaves must be plated before the presence of Phytophthora spp. can be confirmed. Also, although whole English oak leaflets can be plated, it is only feasible to plate random sections of the water-soaked, necrotic tissue of rhododendron leaves, without knowing if the symptoms are caused by Pythium or Phytophthora spp. Particularly, if a higher Pythium population exists in a soil sample, any Phytophthora spp. present may be missed when baiting. Rhododendron leaf disks are commonly used to overcome this problem but wounding bait material favors Pythium spp. colonization, which can considerably reduce success in isolating Phytophthora spp.(41).

We noted that $P$. cinnamomi was isolated more frequently from soil types that hold more moisture and nutrients (e.g., silts and loams), though the California Soil Resource Lab's SoilWeb mapping tool is somewhat imprecise at specific locations. Nevertheless, our results correspond with similar studies. A study of $P$. cinnamomi causing disease on cork oak $(Q$. suber) in Portugal noted that, although P. cinnamomi was not significantly associated with any one soil type, it was more frequently isolated from soils with a higher silt or clay content (45). In Germany, a significant association was found between Phytophthora spp. and their presence in soils with a loamy, silty, or clayey texture but not for sandy or sandy loam soils (34). Similarly, in Swedish oak forests, Phytophthora spp. were isolated from all textures but sandy (29). In southern Ohio, soils free of $P$. cinnamomi also had a much higher percentage of sand than infested, clayey soils collected from a white oak stand (46). The more frequent isolation of P. cinnamomi from fine-textured soils may be due to a higher amount of calcium present in non-sandy soils, which have a higher cation exchange

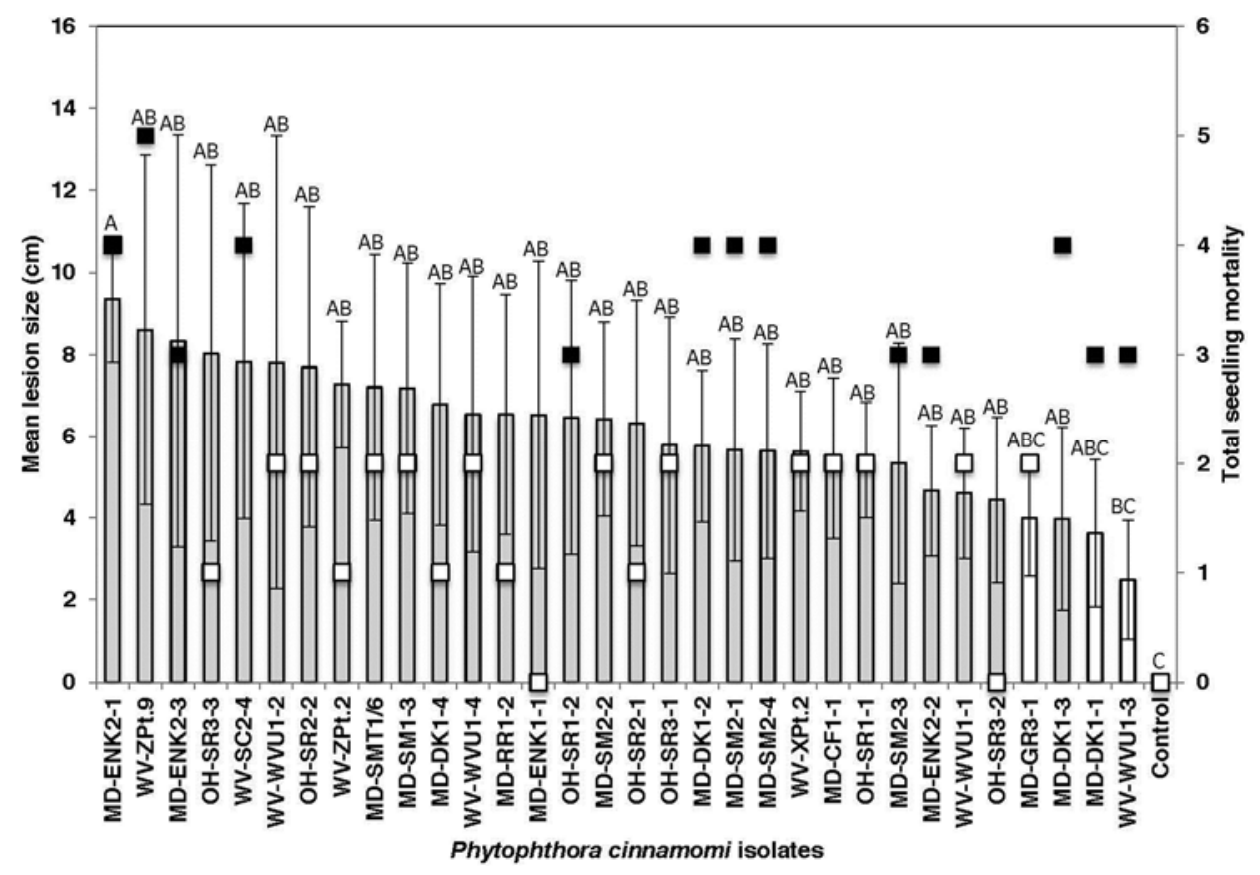

Fig. 3. Average length of stem lesions (bars) and total number of 1-year-old Quercus alba seedlings killed (boxes) by Phytophthora cinnamomi after 2 months of incubation. Bars indicate standard deviations of lesion sizes. Gray bars and black squares indicate significant differences of mean lesion size or mortality rates, respectively, compared with controls. Black squares indicate total mortality for the group of 10 seedlings inoculated with each isolate. Column means not followed by the same letter are significantly different. 
capacity (12,34). Calcium is a necessary element needed for both growth and reproduction of Phytophthora spp. (20), which may explain why soils with a finer texture result in a greater number of Phytophthora isolations. Although most oak forest studies in $\mathrm{Eu}-$ rope and the United States could not detect $P$. cinnamomi in sandy soils, studies of the distribution of $P$. cinnamomi in sandy soils illustrate that the organism is not often found close to the soil surface $(43,56)$. The pathogen was found in sandy soils in Australia at a depth of approximately $1 \mathrm{~m}$ and in North and South Carolina at $70 \mathrm{~cm}(44,55,56)$. Therefore, $P$. cinnamomi may be found far below the soil surface in soils with a higher percentage of sand. Sandy soils of Delaware and Maryland's Eastern Shore should be resampled for $P$. cinnamomi deeper in the soil profile; this procedure might reveal the presence of the pathogen in areas considered to be noninfested in the past.

At infested sites, when sampling was expanded to include other plant species in addition to white oak, Phytophthora spp. were detected from about half of the plant species examined. Although all hosts sampled in this study have known associations with various Phytophthora spp., P. quercetorum was isolated from soil collected from beneath red maple (Acer rubrum) for the first time, and new host associations for P. cinnamomi in soil included red maple, sugar maple (A. saccharum), American beech (Fagus grandifolia), and tulip poplar (Liriodendron tulipifera). P. cambivora and $P$. plurivora were also found in soil from sugar maple for the first time (22).

The P. cinnamomi CFU quantified for various hosts did not differ among the plants sampled but hosts that favor the population growth of $P$. cinnamomi are noted in other environments; yellow lupin (Lupinus luteus) in Spain and bull banksia (Banksia grandis) in Australia are two such examples $(54,56)$. We could not relate CFU with crown dieback or root reduction in this study. In another study, when a white oak forest stand was sampled intensively, CFU levels were seven times greater on declining white oak trees than on oak trees without any crown dieback (10). The same conclusion was reached when $\mathrm{CFU}$ of declining white oak stands of the same forest site were quantified for 2 years and found to be significantly greater at declining trees than at healthy ones both years (46). The latter study also confirmed the field finding in an inoculum doseresponse study using white oak seedlings and showed that greater inoculum levels resulted in significant root damage. Our study compared a wide variety of sites in an attempt to observe general trends but specific site conditions may have a significant impact on CFU levels, making a more general comparison difficult.

The aggressiveness of $P$. cinnamomi on white oak stems was illustrated in this study. Almost all isolates caused significant lesions on white oak seedlings. Furthermore, the isolates were nearly equally aggressive, a testament to the virulence of the $P$. cinnamomi population in eastern U.S. forests. Other studies have also shown the pathogenicity of $P$. cinnamomi isolates from the eastern United States on various oak trees $(6,30,46)$ and, similar to our findings, little variation existed in aggressiveness of $P$. cinnamomi $(18,61)$. Although little difference in pathogenicity was detected among the isolates, variation was found when seedling mortality rates were compared. It is possible that the isolates that caused more seedling mortality girdle stems quickly, rather than causing larger lesions to form. A longer incubation period could eliminate the observed differences between lesion size and mortality rates.

This study provides evidence that $P$. cinnamomi's distribution in eastern U.S. forests may be linked to climate conditions. The distribution of $P$. cinnamomi was delineated by $40^{\circ} \mathrm{N}$ latitude, the approximate boundary between USDA hardiness zones five to the north and six to the south. This observation was previously noted but not evaluated $(3,7,10)$. In our survey, 32 sites were located above $40^{\circ} \mathrm{N}$ latitude and $P$. cinnamomi was never found in these sites. Such limits were not present for the other Phytophthora spp. There was also a difference between zones six and seven in respect to CFU of $P$. cinnamomi: zone seven had twice the amount of CFU in soil. We hypothesize that these differences are related to en- vironmental conditions. Soils north of $40^{\circ} \mathrm{N}$ latitude are not warm enough for a long enough time period each year for the population of $P$. cinnamomi to increase. Soils in hardiness zone five rarely rise above $20^{\circ} \mathrm{C}$ at any point during the year, instead remaining at approximately 15 to $17^{\circ} \mathrm{C}$ during the summer months (64). In contrast, soils in USDA hardiness zones six and seven both reach 24 to $27^{\circ} \mathrm{C}$ but soils in zone seven remain at this range for about 2 months longer each year than soils in zone six (64). In addition, soil temperatures during winter in zone seven are roughly $5^{\circ} \mathrm{C}$ warmer than in zone six. Therefore, it is likely that the soil temperatures in zone seven are the cause for the higher population levels observed for $P$. cinnamomi, and that lower temperatures in zone five prohibit the survival of the pathogen. If temperatures continue to rise due to climate change, $P$. cinnamomi might expand its range in mid-Atlantic oak forests and eventually move northward into zone five. Several past climate models using $P$. cinnamomi have determined that range expansion of the pathogen is likely if temperatures increase $(11,13)$.

Unlike other oak decline studies that used crown symptoms as a way to measure the impact of Phytophthora spp., in this study, we evaluated the root system of white oak trees as a variable that might better demonstrate this interaction. When incidence of Phytophthora spp. was evaluated based on crown symptoms alone, no significant connection was found for either year; however, when data were analyzed including root status as a parameter, a different conclusion was reached. During our first sampling year, reduction of fine roots related to crown dieback at Phytophthora spp.infested sites (data not shown). However, this connection was not present in the second year of the study. This result agrees with some of the previous findings $(9,10,66)$ but also contradicts others where an association was noted based on the crown symptoms alone $(8,16,34,45,53)$. The inconsistent association between Phytophthora spp. in soil, crown status, and root health of declining oak trees illustrates the dynamic changes that occur over time between the plant, pathogen, and environment, and sampling at different time periods provides only a snapshot of a longer progression of decline.

Evaluation of the root system in connection with environmental parameters as reflected by USDA hardiness zones gave a different perspective on the root dynamics of mature white oak trees in the mid-Atlantic region. A difference in fine root status emerged between sampling years regardless of whether or not the pathogen was present. Although fewer roots were available at Phytophthora spp.-infested trees during the first year, in the second year no such connection was found. It is imperative to state that environmental conditions were different between sampling years and an unusual early drought was experienced during the second year of sampling at many of the study sites. When the Palmer Drought Index for January to July of each sampling year was examined, drier conditions were present during the early part of the growing season in 2012 (19). It is possible that, in the first year of the study, more roots were killed because the environment was wetter and more suitable for longer infectious periods. During the second year, when drought occurred, the pathogen was probably not favored because the infectious cycle of Phytophthora spp. depends greatly on available water for dissemination of infectious zoospores and growth within host tissue. Several studies have noted that infection of hosts by $P$. cinnamomi under severe water stress results in growth inhibition of the pathogen $(40,51,63)$.

The effect of environmental conditions on the interaction between host and pathogen became even clearer when data were separated by hardiness zone. In the northern zone five, white oak trees had fewer roots compared with the more southern zones six and seven. This was somewhat expected because cooler temperatures might have contributed to less root production by white oak trees (62). In zone five, presence of Phytophthora spp. significantly reduced the fine roots of trees at infested sites in both years. However, Phytophthora spp. were not consistently associated with root reduction in zone six. Only during the second year, when drought also occurred, was there a significant reduction. During the second 
year, trees had overall fewer roots, which could be a reflection of early growing season drought. It is possible that the impact of Phytophthora spp. became more noticeable because of insufficient root amounts. This suggests that Phytophthora infection in combination with drought could become more important for root health. Site conditions were also suspected to be involved in $Q$. alba mortality caused by $P$. cinnamomi in Ohio (10). Similarly, in $P$. cinnamomiinfected $Q$. suber and $Q$. ilex forests in Europe, site conditions and unusual climatic events were thought to have contributed to a $P$. cinnamomi-induced oak decline $(14,16,24,45,53)$. Such conclusions were also reached with pot experiments; damage to oak seedlings was shown to increase when they were subjected to drought or saturated conditions $(33,40,42,46,53)$. Changing climate conditions in Europe that have resulted in warmer, wetter winters and droughty summers with periods of heavy rainfall are suspected to have changed the delicate balance between oak species and $P$. cinnamomi and may have led to current oak decline problems in certain locations $(13,24)$. The climate in mid-Atlantic U.S. forests is not as warm as the Mediterranean region but, if drought events become more frequent, this phenomenon coupled with isolated periods of heavy rainfall throughout the year may result in previously unseen problems caused by $P$. cinnamomi.

The host-pathogen interaction appears to differ considerably in the warmest hardiness zone, seven, when compared with the two other zones. Although P. cinnamomi CFU were twice as high in this zone, infected trees also had greater amounts of fine roots during both years. This suggests that, despite the pathogen population being higher, fine root production as a host response was also better established in this zone. A similar plant response was also detected in artificial pot inoculation experiments. Tolerant citrus rootstocks were shown to regenerate more roots in the presence of $P$. nicotianae and P. palmivora (69). Similarly, beech trees infected with Phytophthora spp. had greater fine root lengths (47). More fine roots were also noted with various oak seedlings that remained alive after they had been exposed to Phytophthora spp. infection for 18 months under greenhouse conditions (Y. Balci, unpublished). Although the greater fine root amounts collected from zone seven may seem counterintuitive when a fine root pathogen such as $P$. cinnamomi is involved, this change illustrates that there is a definite plant response to the presence of the pathogen. In this region, it is possible that the presence of $P$. cinnamomi induces the formation of more fine roots, stressing the trees as they use stored energy for root production and potentially contributing to decline.

This study is the first to systematically collect fine roots from a large number of oak trees in mid-Atlantic forests to examine the possible effects of $P$. cinnamomi on the root system. We have shown that the presence of Phytophthora spp. can be associated with root health but environmental factors probably play a significant role in this interaction, which has not been previously documented under field settings. The dynamic interactions between host and pathogen in different climatic regions could explain why discrepancies exist among different studies and why we were unable to consistently associate crown symptoms with the presence of the pathogen in soil. Studies examining fine root health over multiple years could provide us with new insight if and when $P$. cinnamomi acts as a trigger of oak decline in areas where its biology is favored. Although we have shown that $P$. cinnamomi has a possible effect on white oak fine roots in this region, white oak decline is most likely not caused by this pathogen alone. Oak decline is often caused by the interplay of multiple factors conceptualized as predisposing, contributing, and inciting $(39,58)$. Some of the most serious threats to white oak in the eastern United States include gypsy moth defoliation, insect borers, competition from successional plant species, drought, and root rot caused by Armillaria spp. $(15,27,36,38)$. It is likely that white oak decline in mid-Atlantic forests is caused by the interaction of some combination of these factors, and that $P$. cinnamomi and, to a lesser extent, other sporadically found Phytophthora spp. are contributors to the decline complex as a whole.

\section{Acknowledgments}

This research was made possible through funding from the USDA Forest Service. We thank our lab members J. C. Bienapfl, M. Breiner, P. Di Bello, B. Ford, D. Reis Gonçalves, L. Thuy Vi Tran Ho, and A. Reis for their invaluable assistance with field sampling, greenhouse inoculations, and laboratory routines over the course of our research; and K. Rane, K. Everts, and A. Grybauskas for their critical evaluation of this manuscript.

\section{Literature Cited}

1. Abrams, M. D. 2003. Where has all the white oak gone? BioScience 53:927-939.

2. Alvarado-Rosales, D., Saavedra-Romero, L. d. L., and Almaraz-Sanchez, A. 2008. First report of Phytophthora cinnamomi Rands. associated with oak (Quercus spp.) in Tecoanapa, Guerrero, Mexico. Agrociencia 42:565-572.

3. Anonymous. 2012. USDA Plant Hardiness Zone Map. USDA Agricultural Research Service. http://planthardiness.ars.usda.gov/PHZMWeb/

4. Balci, Y., Balci, S., Blair, J. E., Park, S.-Y., Kang, S., and Macdonald, W. L. 2008. Phytophthora quercetorum sp. nov., a novel species isolated from eastern and north-central USA oak forest soils. Mycol. Res. 112:906-916.

5. Balci, Y., Balci, S., Eggers, J., MacDonald, W. L., Juzwik, J., Long, R. P., and Gottschalk, K. W. 2007. Phytophthora spp. associated with forest soils in eastern and north-central US oak ecosystems. Plant Dis. 91:705-710.

6. Balci, Y., Balci, S., MacDonald, W. L., and Gottschalk, K. W. 2008. Relative susceptibility of oaks to seven species of Phytophthora isolated from oak forest soils. For. Pathol. 38:394-409.

7. Balci, Y., Balci, S., MacDonald, W. L., Gottschalk, K. W., Juzwik, J., Eggers, J., and Long, R. L. 2005. Phytophthora species in central and eastern U.S. oak ecosystems. (Abstr.) Phytopathology 95:S158.

8. Balci, Y., and Halmschlager, E. 2003. Incidence of Phytophthora species in oak forests in Austria and their possible involvement in oak decline. For. Pathol. 33:157-174.

9. Balci, Y., and Halmschlager, E. 2003. Phytophthora species in oak ecosystems in Turkey and their association with declining oak trees. Plant Pathol. 52:694-702.

10. Balci, Y., Long, R. P., Mansfield, M., Balser, D., and MacDonald, W. L. 2010. Involvement of Phytophthora species in white oak (Quercus alba) decline in southern Ohio. For. Pathol. 40:430-442.

11. Bergot, M., Cloppet, E., Perarnaud, V., Deque, M., Marcais, B., and Desprez-Loustau, M. L. 2004. Simulation of potential range expansion of oak disease caused by Phytophthora cinnamomi under climate change. Glob. Change Biol. 10:1539-1552.

12. Brady, N. C., and Weil, R. R. 2002. The Nature and Properties of Soils, Thirteenth ed. Prentice Hall, Upper Saddle River, NJ.

13. Brasier, C. M. 1996. Phytophthora cinnamomi and oak decline in southern Europe. Environmental constraints including climate change. Ann. For. Sci. 53:347-358.

14. Brasier, C. M., Robredo, F., and Ferraz, J. F. P. 1993. Evidence for Phytophthora cinnamomi involvement in Iberian oak decline. Plant Pathol. 42:140-145.

15. Brazee, N. J., and Wick, R. L. 2009. Armillaria species distribution on symptomatic hosts in northern hardwood and mixed oak forests in western Massachusetts. For. Ecol. Manage. 258:1605-1612.

16. Corcobado, T., Cubera, E., Moreno, G., and Solla, A. 2013. Quercus ilex forests are influenced by annual variations in water table, soil water deficit and fine root loss caused by Phytophthora cinnamomi. Agric. For. Meteorol. 169:92-99.

17. Davidson, C. B., Gottschalk, K. W., and Johnson, J. E. 1999. Tree mortality following defoliation by the European gypsy moth (Lymantria dispar L.) in the United States: a review. For. Sci. 45:74-84.

18. Eggers, J. E., Balci, Y., and MacDonald, W. L. 2012. Variation among Phytophthora cinnamomi isolates from oak forest soils in the eastern United States. Plant Dis. 96:1608-1614.

19. Enloe, J. 2013. Palmer Drought Severity Index. National Oceanic and Atmospheric Administration. http://www.ncdc.noaa.gov/oa/climate/research/ prelim/drought/palmer.html

20. Erwin, D. C., and Ribeiro, O. K. 1996. Phytophthora Diseases Worldwide. American Phytopathological Society, St. Paul, MN.

21. Fan, Z. F., Kabrick, J. M., Spetich, M. A., Shifley, S. R., and Jensen, R. G. 2008. Oak mortality associated with crown dieback and oak borer attack in the Ozark Highlands. For. Ecol. Manage. 255:2297-2305.

22. Farr, D. F., and Rossman, A. Y. 2007. Fungal Databases. Systematic Mycology and Microbiology Laboratory, ARS, USDA. http://nt.ars-grin.gov/ fungaldatabases/

23. Fei, S. L., Kong, N. N., Steiner, K. C., Moser, W. K., and Steiner, E. B 2011. Change in oak abundance in the eastern United States from 1980 to 2008. For. Ecol. Manage. 262:1370-1377.

24. Gallego, F. J., de Algaba, A. P., and Fernandez-Escobar, R. 1999. Etiology of oak decline in Spain. Eur. J. For. Pathol. 29:17-27.

25. Garbelotto, M., Huberli, D., and Shaw, D. 2006. First report on an infestation of Phytophthora cinnamomi in natural oak woodlands of California and its differential impact on two native oak species. Plant Dis. 90:685-685.

26. Gottschalk, K. W., and Wargo, P. M. 1996. Oak decline around the world. Pages 3-13 in: USDA Interagency Gypsy Moth Research Forum. 
27. Jedlicka, J., Vandermeer, J., Aviles-Vazquez, K., Barros, O., and Perfecto, I. 2004. Gypsy moth defoliation of oak trees and a positive response of red maple and black cherry: an example of indirect interaction. Am. Midl. Nat. 152:231-236.

28. Jeffers, S. N., and Aldwinckle, H. S. 1987. Enhancing detection of Phytophthora cactorum in naturally infested soil. Phytopathology 77:14751482.

29. Jonsson, U., Lundberg, L., Sonesson, K., and Jung, T. 2003. First records of soilborne Phytophthora species in Swedish oak forests. For. Pathol. 33:175179 .

30. Jordan, A. P., and Tainter, F. H. 1996. The susceptibility of southern Appalachian oaks to Phytophthora cinnamomi. Castanea 61:348-355.

31. Jung, T., and Blaschke, H. 1996. Phytophthora root rot in declining forest trees. Phyton-Ann. Rei Bot. A. 36:95-101.

32. Jung, T., Blaschke, H., and Neumann, P. 1996. Isolation, identification and pathogenicity of Phytophthora species from declining oak stands. Eur. J. For. Pathol. 26:253-272.

33. Jung, T., Blaschke, H., and Ojlwakf, W. 2003. Effect of environmental constraints on Phytophthora-mediated oak decline in Central Europe. Page 89 in: Phytophthora in Forests and Natural Ecosystems. 2nd Intl. IUFRO Working Party. Murdoch University.

34. Jung, T., Blaschke, H., and Osswald, W. 2000. Involvement of soilborne Phytophthora species in Central European oak decline and the effect of site factors on the disease. Plant Pathol. 49:706-718.

35. Jung, T., Colquhoun, I., and Hardy, G. S. J. 2013. New insights into the survival strategy of the invasive soilborne pathogen Phytophthora cinnamomi in different natural ecosystems in Western Australia. For. Pathol. 43:266-288.

36. Kabrick, J. M., Dey, D. C., Jensen, R. G., and Wallendorf, M. 2008. The role of environmental factors in oak decline and mortality in the Ozark Highlands. For. Ecol. Manage. 255:1409-1417.

37. Kelley, M. B., Fierke, M. K., and Stephen, F. M. 2009. Identification and distribution of Armillaria species associated with an oak decline event in the Arkansas Ozarks. For. Pathol. 39:397-404.

38. LeBlanc, D. C. 1998. Interactive effects of acidic deposition, drought, and insect attack on oak populations in the Midwestern United States. Can. J. For. Res. 28:1184-1197.

39. Manion, P. D. 1981. Tree Disease Concepts. Prentice-Hall, Inc., Englewood Cliffs, NJ.

40. Marçais, B., Dupuis, F., and Desprez-Loustau, M. 1993. Influence of water stress on susceptibility of red oak (Quercus rubra) to Phytophthora cinnamomi. Eur. J. For. Pathol. 23:295-305.

41. Martin, F. N., Abad, Z. G., Balci, Y., and Ivors, K. 2012. Identification and detection of Phytophthora: reviewing our progress, identifying our needs. Plant Dis. 96:1080-1103.

42. Maurel, M., Robin, C., Capron, G., and Desprez-Loustau, M. L. 2001. Effects of root damage associated with Phytophthora cinnamomi on water relations, biomass accumulation, mineral nutrition and vulnerability to water deficit of five oak and chestnut species. For. Pathol. 31:353-369.

43. Meadows, I. M., and Jeffers, S. N. 2011. Distribution and recovery of Phytophthora cinnamomi in soils of mixed hardwood-pine forests of the southeastern USA. N. Z. J. For. Sci. 41:39-47.

44. Meadows, I. M., Zwart, D. C., Jeffers, S. N., Waldrop, T. A., and Bridges, W. C., Jr. 2011. Effects of fuel reduction treatments on incidence of Phytophthora species in soil of a southern Appalachian mountain forest. Plant Dis. 95:811-820.

45. Moreira, A. C., and Martins, J. M. S. 2005. Influence of site factors on the impact of Phytophthora cinnamomi in cork oak stands in Portugal. For. Pathol. 35:145-162.

46. Nagle, A. M., Long, R. P., Madden, L. V., and Bonello, P. 2010. Association of Phytophthora cinnamomi with white oak decline in southern Ohio. Plant Dis. 94:1026-1034.

47. Nechwatal, J., and Osswald, W. 2001. Comparative studies on the fine root status of healthy and declining spruce and beech trees in the Bavarian Alps and occurrence of Phytophthora and Pythium species. For. Pathol. 31:257-273.

48. Nowacki, G. J., and Abrams, M. D. 2008. The demise of fire and "mesophi- cation" of forests in the eastern United States. BioScience 58:123-138.

49. Oak, S., Tainter, F., Williams, J., and Starkey, D. 1996. Oak decline risk rating for the southeastern United States. Ann. Sci. For. 53:721-730.

50. O'Geen, A. T., Beaudette, D. E., and Walkinshaw, M. 2013. SoilWeb: A Delivery System for USDA-NRCS Soil Survey. University of California, Davis.

51. Robin, C., Capron, G., and Desprez-Loustau, M. L. 2001. Root infection by Phytophthora cinnamomi in seedlings of three oak species. Plant Pathol. 50:708-716.

52. Robin, C., Desprez-Loustau, M. L., Capron, G., and Delatour, C. 1998. First record of Phytophthora cinnamomi on cork and holm oaks in France and evidence of pathogenicity. Ann. For. Sci. 55:869-883.

53. Sanchez, M. E., Caetano, P., Ferraz, J., and Trapero, A. 2002. Phytophthora disease of Quercus ilex in south-western Spain. For. Pathol. 32:5-18.

54. Serrano, M. S., Fernandez-Rebollo, P., De Vita, P., Carbonero, M. D., and Sanchez, M. E. 2011. The role of yellow lupin (Lupinus luteus) in the decline affecting oak agroforestry ecosystems. For. Pathol. 41:382-386.

55. Shearer, B. L., and Crane, C. E. 2011. Habitat suitability of soils from a topographic gradient across the Fitzgerald River National Park for invasion by Phytophthora cinnamomi. Australas. Plant Pathol. 40:168-179.

56. Shearer, B. L., Dillon, M. J., Kinal, J., and Buehrig, R. M. 2010. Temporal and spatial soil inoculum dynamics following Phytophthora cinnamomi invasion of Banksia woodland and Eucalyptus marginata forest biomes of south-western Australia. Australas. Plant Pathol. 39:293-311.

57. Shew, H. D., and Benson, D. M. 1982. Qualitative and quantitative soil assays for Phytophthora cinnamomi. Phytopathology 72:1029-1032.

58. Sinclair, W. A. 1966. Decline of hardwoods: Possible causes. Pages 17-32 in: Proc. of the 42nd. Int. Shade Tree Conf., Cleveland, OH.

59. Staley, J. M. 1965. Decline and mortality of red and scarlet oaks. For. Sci $11: 2-17$.

60. Starkey, D. A., Oliveria, F., Mangini, A., and Mielke, M. 2004. Oak decline and red oak borer in the interior highlands of Arkansas and Missouri: natural phenomena, severe occurrences. Pages 217-222 in: Upland Oak Ecol Symp.: History, Current Conditions, and Sustainability. Gen. Tech. Rep. SRS-73. U.S. Dep. Agric. For. Serv., Southern Res. Stn., Asheville, NC.

61. Tainter, F. H., O'Brien, J. G., Hernandez, A., Orozco, F., and Rebolledo, O. 2000. Phytophthora cinnamomi as a cause of oak mortality in the state of Colima, Mexico. Plant Dis. 84:394-398.

62. Teskey, R. O., and Hinckley, T. M. 1981. Influence of temperature and water potential on root growth of white oak. Physiol. Plant. 52:363-369.

63. Tippett, J. T., Crombie, D. S., and Hill, T. C. 1987. Effect of phloem water relations on the growth of Phytophthora cinnamomi in Eucalyptus marginata. Phytopathology 77:246-250.

64. Tolsdorf, T. 2013. Soil Climate Analysis Network. United States Department of Agriculture Natural Resources Conservation Service. http:// www.wcc.nrcs.usda.gov/scan/

65. Van Lear, D. H. 2004. Upland oak ecology and management. Pages 65-71 in: Upland Oak Ecol. Symp.: History, Current Conditions, and Sustainability. U.S. Dep. Agric. For. Serv., Southern Res. Stn., Asheville, NC.

66. Vettraino, A. M., Barzanti, G. P., Bianco, M. C., Ragazzi, A., Capretti, P., Paoletti, E., Luisi, N., Anselmi, N., and Vannini, A. 2002. Occurrence of Phytophthora species in oak stands in Italy and their association with declining oak trees. For. Pathol. 32:19-28.

67. Weste, G., and Marks, G. C. 1987. The biology of Phytophthora cinnamomi in Australasian forests. Annu. Rev. Phytopathol. 25:207-229.

68. White, T. J., Bruns, T., Lee, S., and Taylor, J. 1990. Amplification and direct sequencing of ribosomal RNA genes for phylogenetics. Pages 315-322 in: PCR Protocols: a Guide to Methods and Applications. M. Innis, D. H. Gelfand, J. J. Sninsky, and T. J. White, eds. Academic Press, Inc., San Diego, CA and London.

69. Widmer, T. L., Graham, J. H., and Mitchell, D. J. 1998. Histological comparison of fibrous root infection of disease-tolerant and susceptible citrus hosts by Phytophthora nicotianae and Phytophthora palmivora. Phytopathology 88:389-395.

70. Wood, A. K., and Tainter, F. H. 2002. First report of Phytophthora cinnamomi on Quercus laurifolia. Plant Dis. 86:441. 